\title{
Changes in total oil hydrocarbon composition during degradation with sorbent bacterial preparation
}

Indrè Gailiūtè,

\author{
Monika Kavaliauskė, \\ Jolanta Aikaitè-Stanaitiené $\dot{x}^{*}$
}

JSC "Biocentras",

V. Graičiūno st. 10,

LT-02241 Vilnius,

Lithuania
Accidental or deliberate spillage of crude oil into the environment is leading to serious pollution problems. Therefore, these areas of oil pollution can be decontaminated by microorganisms. However, biological degradation capabilities of oil and its derivatives, also their effect on living organisms and on the environment varies. Microorganisms that degrade oil hydrocarbons are found in almost all types of soil; however, their existence does not guarantee the effective degradation of oil pollutants.

In order to evaluate capabilities of newly developed SORBENT bacterial preparation (SBP) to degrade heavy hydrocarbons, degradation dynamics was observed in different soil types: loam, clay and sand, using crude oil and fuel oil mixture $(1: 1)$. Therefore, correlation between the intensity of oil component degradation and temperature as well as a correlation between the intensity of oil fraction degradation and the amount of SBP were evaluated. According to experimental data, soil samples polluted with heavy hydrocarbons and treated with SBP, during the first 9 weeks of biodegradation were composed of: up to $20-30 \%$ of alkanes, $30-50 \%$ of aromatic compounds, $50-60 \%$ of resins and $9-44 \%$ of asphaltenes. The investigations revealed that less polluted soil (up to $100 \mathrm{~g} / \mathrm{kg}$ ) treated with microorganisms was degraded almost 6 times better than heavily polluted soil $(350 \mathrm{~g} / \mathrm{kg})$. Therefore, it can be stated that SBP is very effective in the degradation of all types of oil hydrocarbons, including resins and asphaltenes, which are known as the most difficult ones to degrade.

This paper reflects findings from the EU funded 7th Framework programme project “SORBENT" (232533).

Key words: bacterial preparation, heavy oil hydrocarbons, oil degradation, oil fractions, soil pollution

\section{INTRODUCTION}

Crude oil and petroleum products are highly complex mixtures of organic compounds. Petroleum hydrocarbons that constitute crude oil are categorized into four fractions: saturates (aliphatics), aromatics, resins and asphaltenes [1]. These fractions and their derivatives are the main pollutants in the environment. They are a serious concern worldwide because of the hazard they pose to the

\footnotetext{
* Corresponding author. E-mail: jolanta@biocentras.lt
}

The paper was presented at the 5th International conference “Vital Nature Sign”, Kaunas, Lithuania, May 19-21, 2011. health of humans and animals [2]. The aliphatic and some aromatic fractions of hydrocarbons are mostly biodegradable components. Whereas, resins and asphaltenes are considered to be the most resistant ones to biodegradation [3-5]. Degradation level of different oil hydrocarbon groups depends not only on the composition of oil, but also on the capability of microorganisms to degrade different classes of oil hydrocarbons. Firstly, microorganisms degrade the most available hydrocarbons, and after their concentration lowers, the degradation process also slows down, as the remaining hydrocarbons are more difficult to degrade. Therefore, the composition of hydrocarbons changes when degradation of some oil hydrocarbons ex- 
ceeds the degradation of others. However, when a mixed substrate of hydrocarbons is investigated, the compound resistance to biodegradation is more difficult to observe. Environmental conditions and chemical composition of petroleum products influence the intensity of biodegradation.

The SORBENT system (S-S) is targeted to reduce the concentration of oil contaminants to an acceptable level for starting up the biodegradation process. It is based on lowcost natural organic SORBENT material from paper mill waste short fibers, which is embedded with a specific biosurfactant, acting as an activating agent for microorganisms to produce biosurfactant for the further decontamination. In the $\mathrm{S}-\mathrm{S}$ biosurfactant is used to increase the bioavailability of contaminants to soil microbial degraders by reducing contaminant viscosity and increasing the solubility of hydrocarbons. Therefore, the microbial cells are responsible for producing bio-surfactants.

Oil degrading microorganisms have to be applied to polluted soil and / or water. So, it is highly important to select oil-oxidizing microorganism strains that are able to use oil hydrocarbons as their primary source of carbon and energy. Therefore, five microbial cultures belonging to genus Arthrobacter that are able to degrade heavy hydrocarbons were selected for the project purposes. Finally, the most effective combination of strains: Arthrobacter sp. NJ5 and N3 was selected for the composition of SBP.

In order to evaluate SORBENT bacterial preparation capabilities to degrade petroleum fraction substrates, a mixture of crude and fuel oil $(1: 1)$ was used to test the degradation dynamics in different types of soil: loam, clay and sand.

The evaluation of changes in heavy hydrocarbon mixture (crude oil : fuel oil) was performed after 3 and 9 weeks of experiment with S-S and SBP.

\section{MATERIALS AND METHODS}

\section{Materials}

Crude oil and fuel oil used in this study were obtained from oil refining company "Orlen Lietuva", located in Mažeikiai, Lithuania. During the experiments, a mixture of the oil samples: crude oil and fuel oil was used by a ratio of $1: 1$.

SORBENT system is composed of such components: sorbtic material made from paper mill waste short fibres, $\sim 10^{7} \mathrm{CFU} / \mathrm{g}$ microorganisms, $3 \%$ of biosurfactant, $0.5 \%$ of nitrogen, $0.2 \%$ of phosphorous. Hydrocarbon sorption capacity of S-S was determined at $4.3 \mathrm{~g}$ oil.

SORBENT bacterial preparation. Cultivation of bacterial composition of Arthrobacter sp. NJ5 strain and Arthrobacter sp. N3 was carried out in flasks. The $750 \mathrm{~mL}$ Erlenmeyer flasks containing $70 \mathrm{~mL}$ of complex nutrient medium were incubated at $30^{\circ} \mathrm{C}$ in a rotary shaker Innova 43 (New
Brunswick Scientific Co.) at $200 \mathrm{rpm}$ for $16 \mathrm{~h}$. Both cultures of microorganisms were used in the same amount.

Physical characteristics of soil. In the experiments, three types of soil (loam, clay and sand), which have quite different characteristics, were used.

\section{Biodegradation of crude oil : fuel oil mixture}

In order to evaluate SBP capabilities to degrade substrates of heavy hydrocarbons, an investigation was performed using crude oil : fuel oil mixture $(1: 1)$ to observe degradation dynamics in different soil types - loam, clay and sand.

Oil fraction changes were observed by changing the following conditions: a) amount of biosurfactant; b) amount of SORBENT bacterial preparation and c) temperature.

Correlation between oil fraction degradation, the amount of biosurfactant and SORBENT bacterial preparation (SBP)

The heavy hydrocarbons initial concentration of $100 \mathrm{~g} / \mathrm{kg}$ was used in combination with either 5 or $10 \%$ (by mass) of S-S. SBP was added with the concentration of 0.5 or $5 \%$, together with $\mathrm{NP}$ fertilizer that was a mixture of $\mathrm{NH}_{4} \mathrm{NO}_{3}$ and $\mathrm{KH}_{2} \mathrm{PO}_{4}(6: 1)$. The moisture of samples was kept at $20-30 \%$, under the temperature regime of $22^{\circ} \mathrm{C}$.

\section{Correlation between oil fraction degradation and tem-} perature

A mixture of crude oil and fuel oil $(1: 1)$ with the initial concentration of $350 \mathrm{~g} / \mathrm{kg}$ was used, combined with $5 \%$ (by mass) of S-S. SBP was added at the concentration of $5 \%$, together with NP fertilizer that was a mixture of $\mathrm{NH}_{4} \mathrm{NO}_{3}$ and $\mathrm{KH}_{2} \mathrm{PO}_{4}(6: 1)$. The moisture of samples was kept at $20-$ $30 \%$, under three different temperature regimes of $+4{ }^{\circ} \mathrm{C}$, $+22{ }^{\circ} \mathrm{C}$ and $+40{ }^{\circ} \mathrm{C}$.

Evaluation of the changes in heavy hydrocarbons mixture (crude oil : fuel oil) was performed after 3 and 9 weeks of the experiment with S-S and SBP in both experiments. Arthrobacterb sp. NJ5 and N3 strains $(1: 1)$ were used on the soil polluted with hydrocarbons to determine oil degradation dynamics.

\section{Analytical methods}

Composition of the hydrocarbon fraction of crude oil : fuel oil mixture was determined by using gravimetric and column chromatography methods.

Hydrocarbons were extracted with trichlormethane. After the evaporation of the solvent, hydrocarbons were again solved in n-penthane. Since asphaltenes are insoluble in $\mathrm{n}$-penthane, they were separated by centrifugation. Their amount was counted using a gravimetric method. The n-penthane soluble crude oil/fuel oil compounds were fractioned into saturated, aromatic and resin frac- 
tions by the methods of column chromatography, using different solvent phases: $\mathrm{n}$-hexane (for saturated compounds), n-hexane and trichlormethane mixture (1:1 $\mathrm{v} / \mathrm{v}$; for aromatic) and trichlormethane/methanol mixture (1: $1 \mathrm{v} / \mathrm{v}$, for resins). All samples were analyzed in triplicate and results were expressed as a mean value and standard deviation.

\section{RESULTS AND DISCUSSION}

Environmental conditions sometimes are not appropriate for the microbial activity, therefore, hazardous compounds persist in the subsurface that results in biochemical degradation. The optimization of environmental conditions is achieved by understanding the biological principles, under which these compounds are degraded, and the effect of environmental conditions on both: responsible microorganisms and their metabolic reactions. To achieve optimal degradation conditions for any organic compound three main factors have to be considered: knowledge about microbial community, environmental conditions and structure as physicochemical characteristics of the organic compound to be degraded.

Developed S-S was used for the first-step treatment to reduce the contaminant concentration to an acceptable level for starting up the biodegradation process. This system is targeted to collecting oil products after the spill and for control of hydrocarbons level (including heavy hydrocarbons) on soil. S-S is based on low-cost natural organic SORBENT material which is embedded with spe- cific biosurfactant acting as an activating agent for microorganisms to produce more biosurfactant for further cleaning. Microorganisms are responsible for producing biosurfactant capable to separate the migration fraction of oil. For stabilization and preservation of these specific microorganisms $S-S$, relevant nutrients, nitrogen and phosphorus are added.

Bioremediation is considered as a cost efficient method for the treatment of oil contaminants. Therefore, isolation of petroleum degraders is important to petroleum microbiology. During bioremediation, microorganisms use organic contaminants for their growth. During the SORBENT project realization, microorganism strains, capable of degrading oil hydrocarbons, were selected and the SBP was developed; which contains Arthrobacter sp. NJ5 and N3 strains that use oil as the sole source of carbon and energy.

Correlation between oil fraction degradation intensity, amount of biosurfactant and SORBENT bacterial preparation

During the first stage of testing, concentration of biosurfactant was determined using different amounts of the S-S - 5\% and $10 \%$ - since biosurfactant is a part of the S-S.

It is shown in Figures 1 and 2 that crude oil : fuel oil hydrocarbon mixture degradation was performed by the microorganisms of SBP. During the first 3 weeks saturated hydrocarbons had the highest degradation level that was found in all types of soil using either 5 or $10 \%$ of the S-S. This trend was also observed after 9 weeks of degradation.

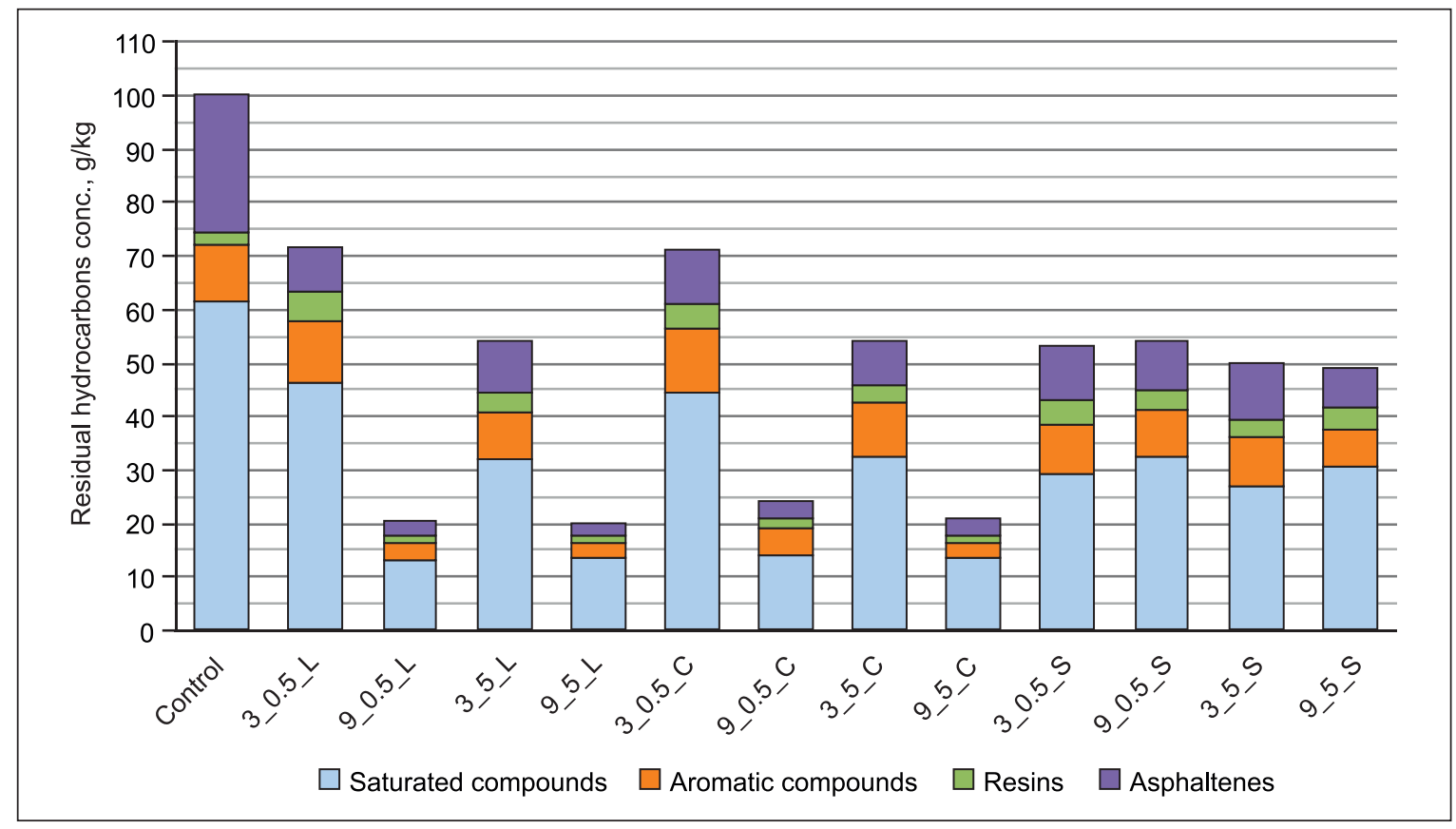

Fig. 1. Residual concentration of oil and its components during biodegradation in soil with $5 \% \mathrm{SS}$ (where: $\mathrm{L}$ - in loam, $\mathrm{C}$ - in clay, $\mathrm{S}$ - in sand; 3_0.5_L - loam (clay or sand) contaminated with oil (100 g/kg), $0.5 \%$ (or 5\%) of SBP added. Results were calculated after 3 (or 9) weeks) 


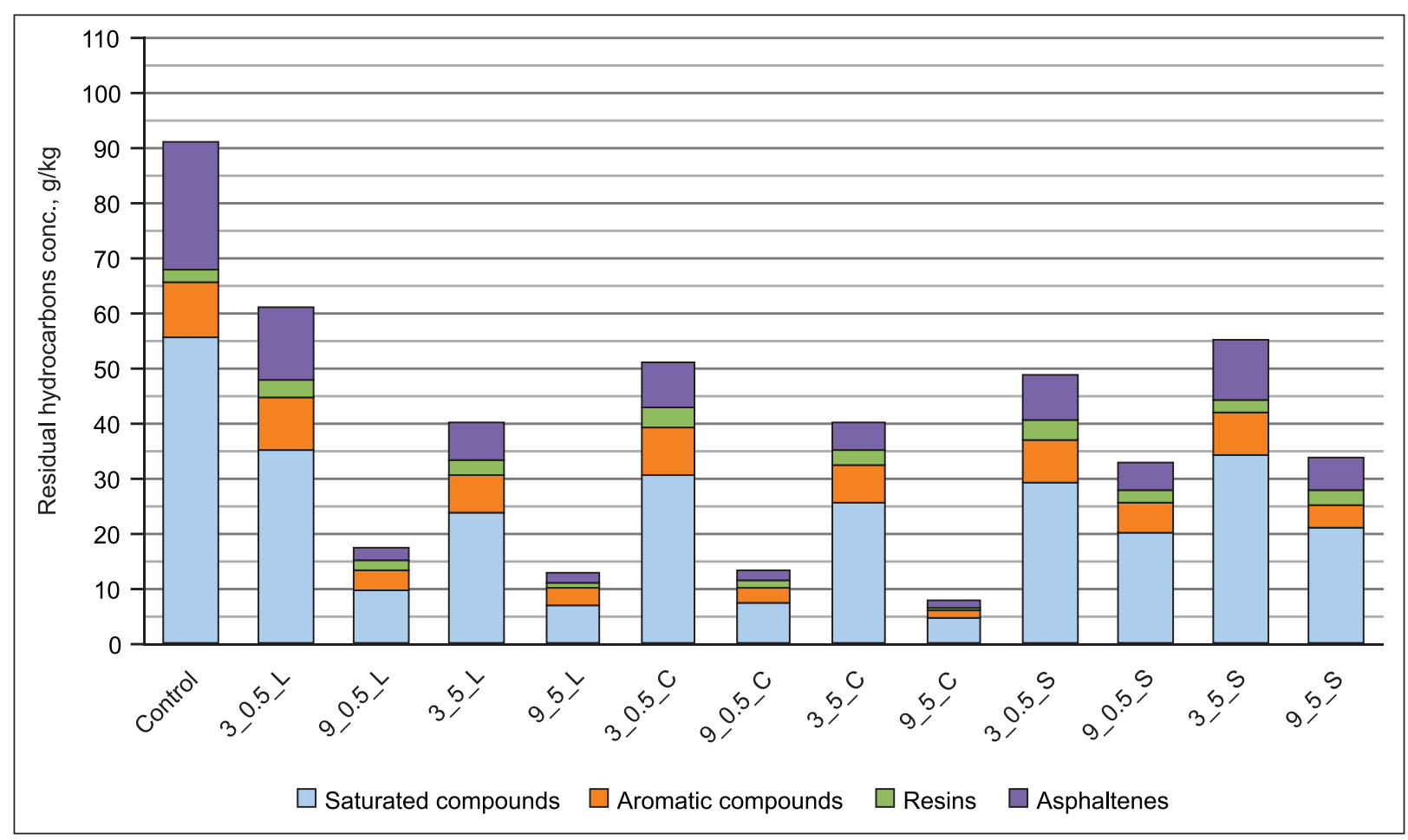

Fig. 2. Residual concentration of oil and its components during biodegradation in soil with $10 \%$ SS (where: $\mathrm{L}$ - in loam, $\mathrm{C}$ - in clay, $\mathrm{S}$ - in sand; 3_0.5_L - loam (clay or sand) contaminated with oil (100 g/kg), 0.5\% (or 5\%) of SBP added. Results measured after 3 (or 9) weeks)

Comparing the results of saturated compound degradation levels, acquired using $0.5 \%$ and $5 \%$ of SBP in all three soil types, it is shown that the degradation was higher when $5 \%$ of SBP was used compared to the $0.5 \%$, during all time periods. Lower degradation of saturated compounds in sand, compared with loam and clay, was observed with 5\% of SBP and $5 \%$ of S-S, than with $10 \%$ of S-S.

Comparing the results of hydrocarbon group degradation levels in different types of soil (loam, clay and sand) with the initial $100 \mathrm{~g} / \mathrm{kg}$ pollutant concentration, we can conclude that the hydrocarbon group composition has changed after 9 weeks of the experiment (Fig. 3).

Highest changes in oil component levels were found after 9 weeks in loam. The investigation results show, that microorganisms in SBP are the most effective in degrading saturated hydrocarbons, while asphaltenes and resins are degraded more slowly. Under crude oil : fuel oil initial mixture concentration of $100 \mathrm{~g} / \mathrm{kg}$ (using $5 \%$ of S-S and $5 \%$ of SBP), 9 weeks after biodegradation under $22{ }^{\circ} \mathrm{C}$ temperature, the pollutant concentration in loam was $12.7 \mathrm{~g} / \mathrm{kg}$, in clay - $7.77 \mathrm{~g} / \mathrm{kg}$ and $33.6 \mathrm{~g} / \mathrm{kg}$ in sand. The groups of oil components are shown in Fig. 3. It is clear that in loam (Fig. 3b) the level of saturated compounds is smaller (51\%) than in the initial mixture (61\%; Fig. 3a), and after biodegradation in sand, the levels of these compounds are slightly elevated (up to $\sim 62 \%$ ). The highest saturated compound changes were seen in clay $(\sim 76 \%$; Fig. 3c). Almost in all soil types aromatic compounds, resins and asphaltens were higher in percentage after biodegradation when compared to the initial oil component groups. It shows that these compounds are degraded more slowly that the saturated ones. Similar results were published by Ogbo and Okhuoya [4] on Pleurotus tuberregium driven oil component biodegradation. After 6 months of investigating biodegradation, they found that the reduction of asphaltenes was low and some substrates instead of decreasing were recorded to be increased in the asphaltic fraction. The differences in biodegradability of hydrocarbon groups determine the degradation speed of different compounds. For example, in one case the easiest components can be degraded in the hydrocarbon mixture first, whilst, in other cases the substrate is only degraded through co-metabolic oxidation [6].

As research shows, the total amount of resins tends to elevate. The biggest amounts found in the samples were up to $6.8 \%$ in loam, $7.2 \%$ in clay and $8.7 \%$ in sand. The main reason for the elevation of the resin amount is, probably, the polymerization reactions that take place when the heavy, oxidized fractions, combine with humus and other soil particles. The heavy fraction accumulation in soil was also shown in researches carried out by other authors [7-9].

According to our experimental data, pollution of heavy hydrocarbons (crude oil : fuel oil mixture) in soil samples after the application of SBP can be reduced up to $20-30 \%$ of alkanes, $30-50 \%$ of aromatic compounds, $50-60 \%$ of res- 


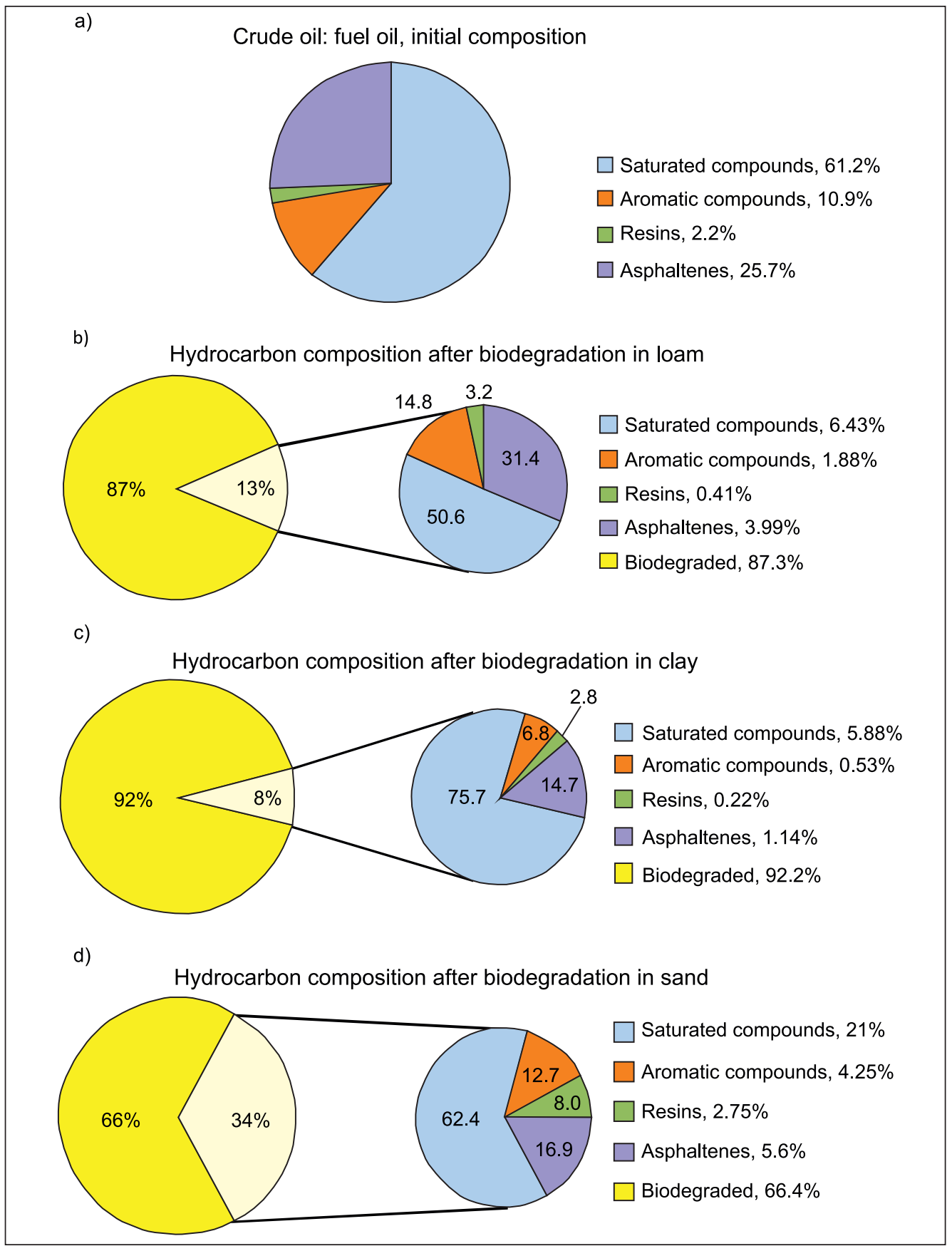

Fig. 3. Composition of oil components after 9 weeks of biodegradation, under $22{ }^{\circ} \mathrm{C}$ temperature, using $5 \%$ of SS and $5 \%$ of SBP

ins (though sometimes resin and asphalten accumulation is seen) and $9-44 \%$ of asphaltenes during the first 9 weeks of biodegradation (Figs. 4, 5). The investigations reveal that in case of less polluted soil (up to $100 \mathrm{~g} / \mathrm{kg}$ ) treated with microorganisms, biodegradation is almost 6 times more active than in the case of heavily polluted soil $(350 \mathrm{~g} / \mathrm{kg})$. The total amount of resins was elevated in almost all samples, comprising up to $50 \%$ of the initial fraction amount.

Therefore, it can be stated that SBP is very effective in the degradation of all types of oil hydrocarbons, including resins and asphaltenes, which are the most difficult to degrade.
Correlation between oil component degradation intensity and temperature

The investigation shows that the most intensive degradation of the crude / fuel oil mixture occurs under $+22{ }^{\circ} \mathrm{C}$ temperature and slightly slower - under $+40{ }^{\circ} \mathrm{C}$ temperature, while the process is slow, but still happening under $+4{ }^{\circ} \mathrm{C}$ (Fig. 6). The tests were carried out with the initial $350 \mathrm{~g} / \mathrm{kg}$ hydrocarbon concentration. $5 \%$ of S-S and 5\% of SBP were used for biodegradation of oil hydrocarbons. Oil component degradation intensity was measured under different temperature conditions: $+4{ }^{\circ} \mathrm{C},+22{ }^{\circ} \mathrm{C}$ and $+40^{\circ} \mathrm{C}$. 


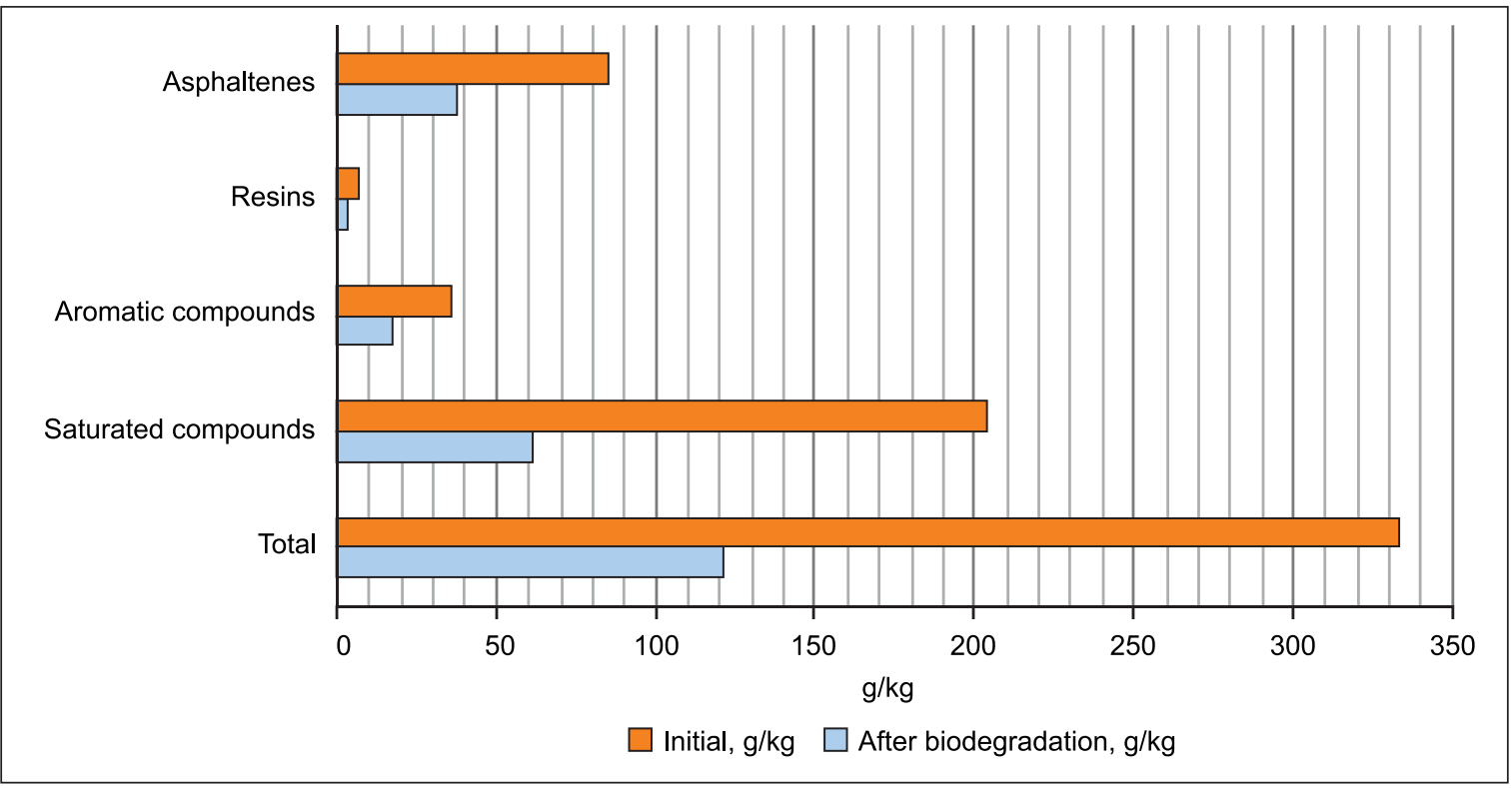

Fig. 4. The effect of SBP on the separate oil fraction levels in a heavily polluted soil (initial conc. $350 \mathrm{~g} / \mathrm{kg}$; after 9 weeks of treatment with $5 \%$ of SBP; biodegradation under $22^{\circ} \mathrm{C}$, with $5 \%$ of the SS)

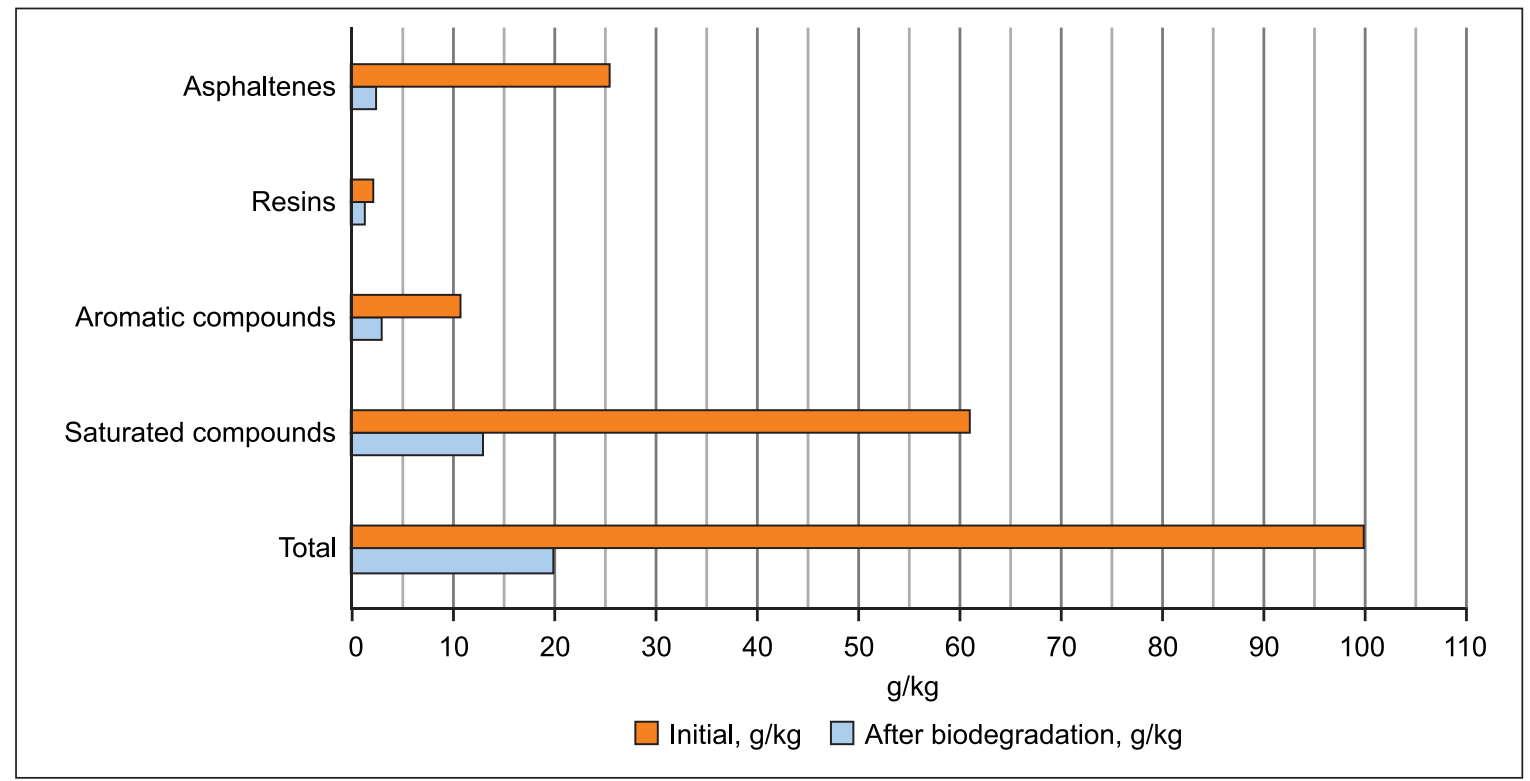

Fig. 5. The effect of SBP on the oil fraction levels in a polluted soil (initial conc. $100 \mathrm{~g} / \mathrm{kg}$; after 9 weeks of treatment with $5 \%$ of SBP; biodegradation under $22{ }^{\circ} \mathrm{C}$, with $5 \%$ of the SS)

During the evaluation of total oil hydrocarbon biodegradation, it was determined that biodegradation occurred most efficiently in loam and clay (after 9 weeks $63.5 \%$ and $40.9 \%$ of total oil hydrocarbons were degraded, respectively) at $22^{\circ} \mathrm{C}$ temperature. Slower degradation was measured in the same types of soil when the temperature was $40{ }^{\circ} \mathrm{C}$ (56.1\% and $22.8 \%$, respectively). However, in sand oil hydrocarbons biodegradation was the highest at $40{ }^{\circ} \mathrm{C}$ temperature, while after 9 weeks total oil hydrocarbons were degraded by $46.0 \%$, and a slightly lower degradation occurred at $22{ }^{\circ} \mathrm{C}$ temperature (42.9\%).
After analyzing the results of saturated compound biodegradation, it can be concluded that degradation in clay sample occurred best at $22{ }^{\circ} \mathrm{C}(40.4 \%)$. In loam and sand, the saturated compounds were degraded the fastest at $40^{\circ} \mathrm{C}$ (75.2 and $39.6 \%$, respectively), with a slower degradation at $22{ }^{\circ} \mathrm{C}(69.8$ and $33.1 \%)$.

Comparing the aromatic compound biodegradation, we can see that at $22^{\circ} \mathrm{C}$ temperature the most intense degradation is in loam and sand (50.5 and 47.2\%). However, these compounds are degraded slower when the temperature rises up to $40{ }^{\circ} \mathrm{C}$ (31.7 and $40.3 \%$, respectively). In 


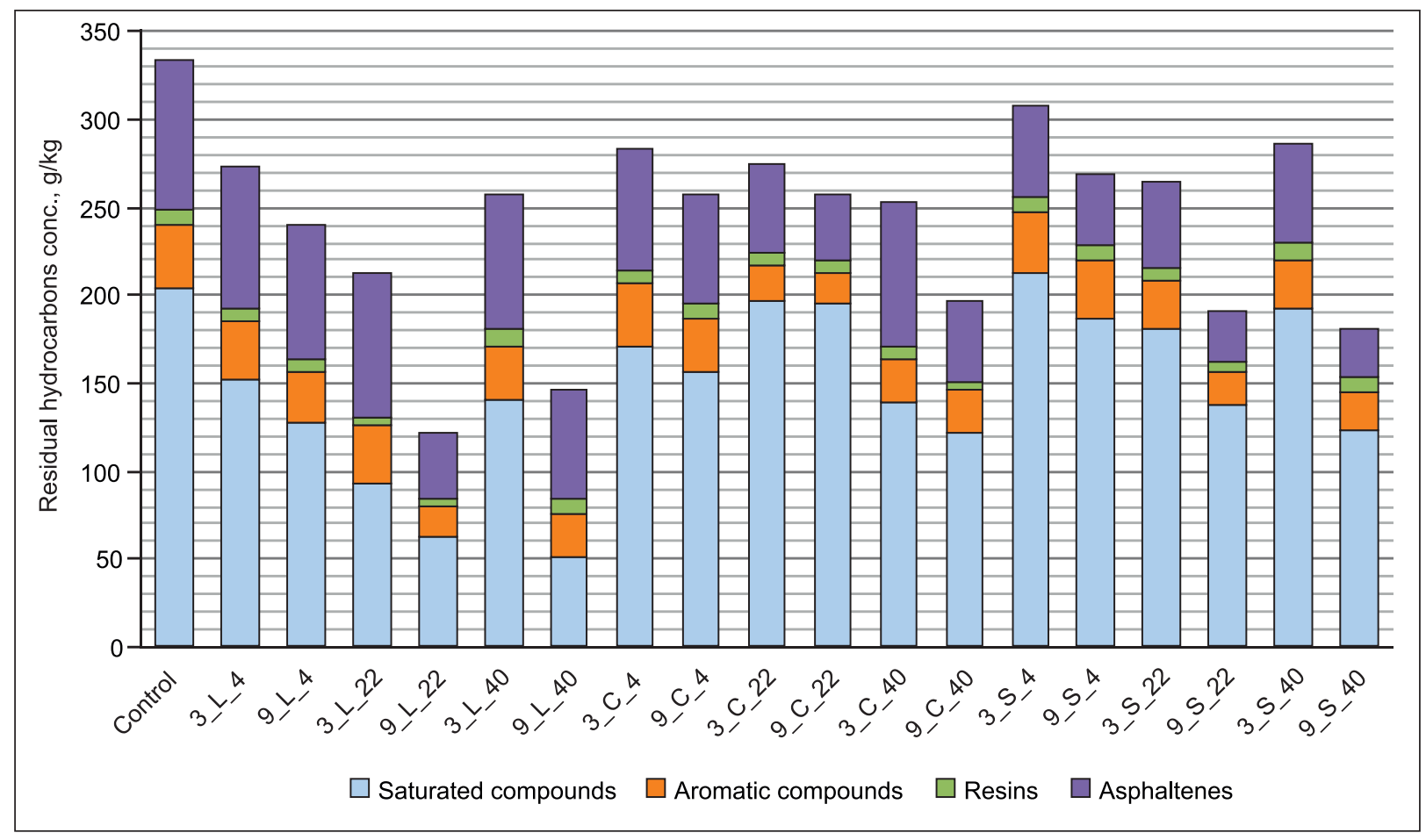

Fig. 6. Correlation between oil components degradation intensity and temperature in different soil types (where: $\mathrm{L}$ - in loam, $\mathrm{C}$ - in clay, $\mathrm{S}$ - in sand; 3_L_4 - the result measured after 3 (or 9) weeks) in loam (clay or sand) contaminated with oil ( $350 \mathrm{~g} / \mathrm{kg}, 5 \%$ of SBP added) biodegraded in $4^{\circ} \mathrm{C}$ (or $22^{\circ} \mathrm{C}$ or $40^{\circ} \mathrm{C}$ ) temperature)

comparison, hydrocarbon degradation in clay soil was higher at $40{ }^{\circ} \mathrm{C}$ temperature than in a sample kept at $22{ }^{\circ} \mathrm{C}$ temperature (51.8 and $34.5 \%$ ).

Resin degradation in loam, clay and sand samples was the highest at $22^{\circ} \mathrm{C}$ temperature. A slight increase in those compounds was seen when degradation occurred at $+4{ }^{\circ} \mathrm{C}$ in clay and sand (higher by 11.1 and $29.4 \%$, respectively), also at $40{ }^{\circ} \mathrm{C}$ temperature in loam and sand (higher by 14.5 and $3.6 \%$, respectively).

The asphaltenes were degraded the fastest in loam at $22{ }^{\circ} \mathrm{C}$ temperature (55.4\%). Yet, their degradation was slower at $40{ }^{\circ} \mathrm{C}$ temperature (27.2\%). However, in sand those compounds were degraded fastest at $40{ }^{\circ} \mathrm{C}$ temperature (67.9\%) and slightly slower at $22{ }^{\circ} \mathrm{C}(66.1 \%)$. Furthermore, in clay, as well as in sand, the biodegradation was most intense at $40{ }^{\circ} \mathrm{C}$ temperature, and slightly slower oxidation occurred at $22{ }^{\circ} \mathrm{C}(55.9$ and $45.7 \%$, respectively).

In all of the tested soil types, the slowest biodegradation of almost all oil hydrocarbons fractions was observed at $+4{ }^{\circ} \mathrm{C}$ temperature.

In conclusion, it can be seen that using a higher amount of S-S (10\%) and SBP (5\%), oil hydrocarbons are degraded faster than with $5 \%$ of S-S and $0.5 \%$ of SBP in different soil types. The fastest degradation was observed in loamy soil, while the slowest was seen in sand under the same initial oil pollutant concentration $(100 \mathrm{~g} / \mathrm{kg})$ and the environmental conditions $\left(+4^{\circ} \mathrm{C}\right)$. It confirms the fact that if the initial oil hydrocarbon pollutant concentration heightens, the degradation process in soil slows down.

Large amounts of fuel oil slow down the biodegradation. In Lithuania, the highest allowed doses of oil product pollution in various soil types are under $50 \mathrm{mg} / \mathrm{kg}$ of dry soil (Lithuanian Hygiene standard, 2004). However, the soil might be polluted with oil products hundred or even thousand times more than the allowed standards. Therefore, soil bioremediation requires more effective and new methods.

\section{CONCLUSIONS}

SBP is very effective in degrading all kinds of hydrocarbons, including resins and asphaltens, which are the most difficult to degrade. Loam was the soil where degradation occurred most intensively, followed by quite similar results in clay, but the slowest biodegradation was observed in sand. The bigger amount of biosurfactant (10\% of S-S instead of 5\%) and SORBENT bacterial preparation (5\% of SBP instead of $0.5 \%)$ was used, the higher biodegradation was achieved, especially during longer time periods ( 9 weeks instead of 3 ). SBP can reduce the concentration of alkanes up to $20-30 \%$, aromatic compounds up to $30-50 \%$, resins up to $50-60 \%$, and asphaltenes up to $9-44 \%$ during the first 9 weeks of biodegradation. The investigations reveal that in case of less polluted soil (up to $100 \mathrm{~g} / \mathrm{kg}$ ) treated with microorganisms, 
biodegradation is almost 6 times more active than in the case of heavily polluted soil $(350 \mathrm{~g} / \mathrm{kg}$ ).

The newly developed SORBENT bacterial preparation effectively degraded various compounds found in the crude/fuel oil mixture. During our investigation, microorganisms, their adaptation abilities and bioremediation process in the polluted soil were affected by extreme environmental conditions. However, the intensity of degradation is observed at moderate temperatures (in case of investigation at $22{ }^{\circ} \mathrm{C}$ ), but not as high as $40^{\circ} \mathrm{C}$. Though, the degradation is also performed at quite low temperatures as $4{ }^{\circ} \mathrm{C}$, it is not very intensive. Hence, according to the findings, the microorganisms of SBP can be used effectively for bioremediation of soil polluted with heavy hydrocarbons in various climate zones.

\section{ACKNOWLEDGMENTS}

This paper reflects findings from the EU funded 7th Framework programme project "SORBENT" (232533).

Received 25 March 2011

Accepted 31 August 2011

\section{References}

1. Singh H. Mycoremediation Fungal Bioremediation. John Wiley \& Sons Inc., Hoboken. New Jersey 2006: 484-532.

2. Reddy CA, Mathew Z. Bioremediation potential of white rot fungi. Fungi in bioremediation. G. M. Gadd Cambridge, U. K.: Cambridge University Press, 2001.

3. Atlas R. Microbial degradation of petroleum hydrocarbons: an environmental perspective. Microbiol Rev 1981; 45: 180-209.

4. Ogbo EM, Okhuoya JA. Biodegradation of aliphatic, aromatic, resinic and asphaltic fractions of crude oil contaminayted soils by Pleurotus tuber-regium Fr. Singer - a white rot fungus. African Journal of Biotechnology 2008; 7(23): 4291-7.

5. Oudot J, Dupont L, Haloui S, Roquebert MF. Biodegradation Potential of Hydrocarbon - assimilating Tropical Fungi. Biol n Biochem 1993; 25: 1167-73.

6. Koronelli TV, Nesterova ED. Ecological strategies of bacteria utilizing hydrophobic substrates. Mikrobiologija 1990; 59(6); 993-7.

7. Bossert I, Bartha R. The fate of petroleum in soil ecosystems. In: Atlas RM (ed). Petroleum Microbiology, Macmillan Publlishing Co, New York 1984: 435-73.

8. Kalèdienè L. Naftą oksiduojantys mikroorganizmai (NOM) / Aplinkos biologinis valymas. Monografija. Sud. K. Jankevičius, R. Liužinas, V.: Apyaušris, 2003: 99-108.
9. Kästner M. Degradation of aromatic and polyaromatic compounds. In: H. J. Rehm, G. Reed, A. Pühler y P. Stadler (ed). Biotechnology Environmental processes II. Soil decontamination. Willey-VCH. Weinheim 2000: 211-40.

Indrè Gailiūtè, Monika Kavaliauskè, Jolanta Aikaitè-Stanaitienė

\section{NAFTOS SUDĖTIES POKYČIAI BIODEGRADACIJOS SU „SORBENT“ BAKTERINIU PREPARATU METU}

\section{Santrauka}

Atsitiktiniai naftos išsiliejimai sukelia rimtas aplinkos taršos problemas. Tarša naftos angliavandeniliais (NA) gali būti biodegraduojama naudojant mikroorganizmus. Naftos ir jos darinių biodegradacijos galimybès, taip pat šiu junginių poveikis gyviems organizmams ir aplinkai skiriasi. Naftą oksiduojančių mikroorganizmų yra beveik visuose dirvožemiuose, tačiau jų buvimas negarantuoja efektyvios NA degradacijos. Siekiant ịvertinti naujai sukurtą „Sorbent“ bakterinị preparatą (SBP), buvo ištirtas šio preparato gebejjimas skaidyti naftą sudarančius angliavandenilius. Nustatyta NA skilimo kaita ivvairiuose dirvožemiuose - priemolio, molio ir smèlio - kaip teršalus naudojant žalios naftos ir mazuto mišini $(1: 1)$. Tyrimo metu ivvertintas temperatūros poveikis naftos komponentų biodegradacijai, pradinio NA bei SBP kiekio poveikis teršalų skaidymo intensyvumui. Remiantis eksperimentų rezultatais, dirvožemio mèginiai, užteršti NA, naudojant SBP per pirmąsias 9 savaites suskaidè: iki 20-30\% alkanų, 30-50 \% aromatinių junginių, 50-60 \% dervų ir 9-44 \% asfaltenų. Tyrimai rodo, kad mažiau užterštas dirvožemis (iki $100 \mathrm{~g} / \mathrm{kg}$ ) SBP išvalomas beveik šešis kartus greičiau nei dirvožemis, užterštas didelėmis NA koncentracijomis $(350 \mathrm{~g} / \mathrm{kg}$ ). Taigi galime teigti, kad SBP yra labai veiksmingas skaidant visas naftą sudarančias junginių klases, ịskaitant dervas ir asfaltenus, kurie yra žinomi kaip sunkiausiai biodegraduojantys naftos teršalai.

Raktažodžiai: bakterinis preparatas, sunkieji naftos angliavandeniliai, naftos degradavimas, naftos komponentai, dirvožemio tarša 